\title{
UJI AKTIVITAS ANTIBAKTERI FRAKSI AKTIF DARI Chlorella vulgaris B TERHADAP Staphylococcus epidermidis SEBAGAI BAHAN AKTIF ANTISEPTIK
}

\author{
${ }^{1}$ Nur Azizah Suhara, ${ }^{2}$ Elsya Nurul Mauludiyah, ${ }^{3}$ Lu'lu Ulul Albab, ${ }^{4}$ Nur Alifah Suhara, ${ }^{5}$ \\ Indra Topik Maulana.
}

1,2,4,5 Prodi Farmasi, Fakultas Matematika dan Ilmu Pengetahuan Alam, ${ }^{3}$ Fakultas Kedokteran Universitas Islam Bandung, Jl. Tamansari No.1 Bandung 40116

\begin{abstract}
ABSTRAK
Infeksi kulit dapat disebabkan oleh patogen yang bervariasi, salah satunya adalah bakteri. Infeksi kulit yang diakibatkan oleh bakteri tidak hanya berupa infeksi primer tetapi bisa juga menyebabkan infeksi sekunder. Mikroalga hijau (Chlorella vulgaris B) merupakan bahan alam yang mengandung senyawa yang memiliki potensi sebagai senyawa antibakteri, khususnya bakteri penyebab infeksi kulit. Penelitian ini bertujuan menguji aktivitas antibakteri Staphylococcus epidermidis dari ekstrak dan fraksi dari mikroalga hijau (Chlorella vulgaris B) penyebab infeksi kulit. Untuk mengetahui kandungan senyawa di dalam mikroalga hijau (Chlorella vulgaris B) dilakukan penapisan fikokimia, yang menunjukkan adanya kandungan senyawa alkaloid, flavonoid, monoterpen/seskuiterpen, polifenolat, steroid, tannin, dan antrakuinon. Ekstraksi dilakukan dengan metode maserasi dengan pelarut etanol 96\%. Ekstrak yang dihasilkan sebesar 119,3 g. Fraksinasi dilakukan dengan metode ekstraksi cair-cair, menghasilkan fraksi n-heksana sebesar 4,8 g, fraksi etil sebesar $0,7852 \mathrm{~g}$, dan fraksi air sebesar 16,7 g. Hasil pengujian aktivitas antibakteri penyebab infeksi kulit dengan menggunakan metode difusi agar dari fraksi n-heksan pada konsentrasi 5\%, 8\%, dan 10\% menghasilkan zona hambat sebesar $12,1 \mathrm{~mm}, 15,2 \mathrm{~mm}$ dan $16,1 \mathrm{~mm}$. Sedangkan dari fraksi etil asetat dengan konsentrasi 5\%,8\%, dan 10\% menghasilkan zona hambat sebesar 14,1 mm, $15,7 \mathrm{~mm}$ dan 14,10 $\mathrm{mm}$, namun pada fraksi air tidak menghasilkan zona hambat, sehingga dapat disimpulkan bahwa fraksi n-heksan dan etil asetat dari mikroalga hijau (Chlorella vulgaris B) mampu menghambat aktivitas bakteri penyebab infeksi kulit dengan aktvitas terbaik yaitu fraksi nheksan dengan konsentrasi $10 \%$.
\end{abstract}

Kata kunci : Infeksi kulit, Mikroalga hijau (Chlorella vulgaris B), Staphylococcus epidermidis, senyawa antibakteri.

\begin{abstract}
Skin infection caused by various pathogen, one of the is bacteria. Sin infection caused by bacteria not only primary infection, but also secondary infection. Green microalgae (Chlorella vulgaris $\mathrm{B}$ ) is a natural source that has potential antibacterial compounds causes skin infection. This research aims to test an antibacterial activity from the fraction of green microalgae (Chlorella vulgaris B) for Staphylococcus epidermidis bacteria that causes skin infection. To identify the compounds in the green microalgae (Chlorella vulgaris B), phycochemichal screening was tested. The result showed an alkaloid, flavonoid, monoterpene/sesquiterpene, polyphenolic, steroid, tannin, and anthraquinone. Extraction with the maseration method used ethanol $96 \%$ as a solvent. Yield of extract is $119,3 \mathrm{~g}$. Fractionation has been done with liquidliquid extraction method that showed the yield of the $\mathrm{n}$-heksan fraction is 4,7885 g, the yield of the ethyl acetate fraction is $0,7852 \mathrm{~g}$, and the yield of the water fraction is $16.675 \mathrm{~g}$. The result for antibacterial activity showed by agar diffusion methods there was inhibitory zone. From 5\%, 8\%, and 10 concentration of n-hexane fraction showed $12.1 \mathrm{~mm}, 15,2 \mathrm{~mm}$, and 16,1
\end{abstract}


mm inhibitory zone, from 5\%, 8\%, and 10 concentration of ethyl acetate fraction showed 14,1 $\mathrm{mm}, 15,7 \mathrm{~mm}$ dan $14,10 \%$ inhibitory zone, but there was no inhibitory zone at water fraction. so it is concluded that $\mathrm{n}$-hexane and ethyl acetate fraction from green microalgae (Chlorella vulgaris B) could inhibited the bacteria activity that can causes skin infection with the best activity from n-hexane fraction with $10 \%$ concentration.

Keywords : Skin infection, Green microalgae (Chlorella vulgaris B), Staphylococcus epidermidis, antibacterial compound

\section{PENDAHULUAN}

Infeksi kulit diketahui sangat mengganggu bagi penampilan penderitanya. Infeksi kulit dapat merusak lapisan-lapisan pada kulit dengan kedalaman lapisan yang berbeda-beda sehingga menimbulkan manifestasi klinis yang bermacam-macam. Jenis bakteri yang sering menyebabkan infeksi kulit diantaranya Staphylococcus aureus, Streptococcus pyogenes dan Staphylococcus epidermidis. Terjadinya infeksi kulit juga berhubungan dengan penurunan sistem imun, karena kulit merupakan barrier pertama yang dilalui oleh suatu pathogen.

Bakteri golongan Staphylococci merupakan mikroorganisme yang banyak menyebar di lingkungan sekitar dan beberapa bersifat pathogen baik bagi manusia dan hewan (Meskin, 1998). S. epidermidis merupakan salah satu bakteri golongan Coagulase-negative Staphyloccoci (CoNS) yang sering menginfeksi jaringan kulit manusia sehingga mengganggu penampilan penderita. S. epidermidis sebenarnya merupakan flora normal (Meskin, 1998) pada kulit manusia, namun ia disinyalir mampu menghasilkan biofilm ekstrakselular sehingga mampu menghambat aktivitas obat antibiotik serta respon imun dari penderita sehingga menjadikannya sebagai bakteri pathogen oportunistik (ECDC, 2018). S. epidermidis memiliki kemampuan memecahkan lipid ataupun karbohidrat menjadi senyawa asam, seperti asam isovalerat. Senyawa asam ini yang membuat bau pada kaki (Pandey, et al., 2011). Pada wilayah negara berkembang, S. epidermidis juga diketahui merupakan bakteri yang paling sering mencemari peralatan medis seperti cateter intravena, sehingga menyebabkan beberapa pasien terinfeksi (Meskin, 1998; Chessa, et al., 2015). S. epidermidis juga diketahui mampu mencemari peralatan implant medis (Chessa, et al., 2016).

Mikroalga hijau (Chlorella vulgaris B) termasuk ke dalam kelompok Protista mirip tumbuhan. Mikroalga ini mampu hidup dalam perairan tawar maupun asin, dan dapat hidup pada tempat beriklim tropis hingga panas (Safi, et. al., 2014). Berdasarkan hasil penelitian Ghasemi, et al (2007) mikroalga hijau (Chlorella vulgaris 
B) memiliki senyawa aktif chlorellin yang bermanfaat sebagai antimikroba. Berdasarkan penelitian Amaro, et al (2011) adanya kandungan asam lemak didalam Chlorella vulgaris B juga diketahui mampu melawan bakteri G positif maupun G negatif. Disamping itu, adanya senyawa flavonoid pada mikroalga juga mampu menghambat pertumbuhan bakteri Pseudomonas, Bacillus sp., dan Klebsilla sp, sehingga Chlorella vulgaris berpotensi memiliki aktivitas dalam menghambat pertumbuhan bakteri $S$. epidermidis (Syed et al, 2015).

Penelitian ini diharapkan menghasilkan fraksi Chlorella vulgaris yang aktif menghambat pertumbuhan $S$. epidermidis. Isolasi fraksi ini bertujuan untuk meningkatkan efek farmakologi antibiotik dari bahan, sehingga fraksi yang menunjukkan penghambatan aktivitas pertumbuhan bakteri S. epidermidis dapat diformulasikan sebagai bahan aktif untuk dibuat menjadi sediaan spray antiseptik Alasan mengapa bahan aktif yang dipakai berupa fraksi dan bukan isolat didasarkan pada aturan Kepala BPOM no. HK.00.05.41.1384 pasal 34 yang menyatakan bahwa Obat tradisional, obat herbal terstandar dan fitofarmaka dilarang mengandung bahan kimia hasil isolasi atau sintetik berkhasiat obat (KaBPOM RI No. HK.00.05.41.1384, 2005). Oleh karena itu, penelitian ini bertujuan untuk mengisolasi fraksi dari Chlorella vulgaris yang aktif sebagai antimikroba Staphylococcus epidermidis serta sebagai bahan aktif spray antiseptik.

\section{METODE PENELITIAN}

\subsection{Alat}

Alat-alat gelas, neraca analitik, krus porselen, perangkat refluks, corong Buchner, , rotary vacum evaporator, water bath, cawan uap, corong pisah, vortex, pengaduk stirrer, autoklaf, oven, inkubator, cawan petri, chamber KLT.

\subsection{Bahan}

Media untuk bakteri uji:

TSA

Sediaan spray antiseptik:

pine oil, fraksi n-heksan $10 \%$, aquadest

Bahan lain:

Chlorella vulgaris $\mathrm{B}$, etanol 95\%, nheksana, etilasetat, plat KLT GF 254, kertas saring bebas abu, kapas lemak, indikator phenolphthalein, asam asetat glasial, kloroform, KI, natrium tiosulfat, $\mathrm{KOH}$, alkohol, $\mathrm{HCl}, \mathrm{NaOH}$, metanol, Dragendroff, dan penampak bercak spesifik $\mathrm{AlCl}_{3}, \mathrm{FeCl}_{3}$, dan Dragendorff.

\subsection{Bakteri yang digunakan}

Staphylococcus epidermidis ATCC 12228 yang diperoleh dari Laboratorium Farmakologi Prodi Farmasi Universitas Islam Bandung.

\subsection{Metode}

Bahan penelitian yang digunakan yaitu serbuk kering Chlorella vulgaris B yang berasal dari Balai Besar Perikanan 
Budidaya Air Payau (BBPBAP), Jepara, Jawa Tengah. Penelitian dilakukan dengan tahapan sebagai berikut : Skrining fikokimia, standardisasi bahan, ekstraksi, pemekatan, fraksinasi, uji aktivitas antimikroba, selanjutnya dibuat menjadi sediaan spray antiseptik

Bahan terlebih dahulu ditelaah kandungan metabolit sekundernya dengan metode Tiwari P et al (2011) dan Octaviani dkk (2019). Adapun senyawa yang ditelaah meliputi alkaloid, flavonoid, antrakuinon, steroid dan triterpenoid, monoterpenoid dan sesquiterpenoid, tanin, dan saponin.

Bahan kemudian distandardisasi meliputi penetapan kadar air, kadar sari larut air dan etanol, kadar abu total dan abu tidak larut asam. Ekstraksi senyawa dilakukan dengan metode maserasi selama 24 jam dan dilakukan pengulangan sebanyak 3 kali. Ekstrak kental kemudian difraksinasi melalui metode Ekstraksi Cair-Cair dengan pelarut nonpolar, semi polar, dan polar. Senyawa pada fraksi dilakukan pemisahan dengan metode KLT. Selanjutnya dilakukan pengujian aktivitas antimikroba dengan metode difusi agar. Konsentrasi masingmasing fraksi (n-heksana, etil, dan air) adalah 5\%, 8\%, dan $10 \%$ dengan jumlah yang dimasukkan ke dalam sumur sebanyak $50 \mu \mathrm{L}$. Selanjutnya diinkubasi pada suhu $37^{\circ} \mathrm{C}$ di inkubator selama 24 jam, kemudian dilihat zona bening yang terbentuk. Fraksi yang menunjukkan penghambatan aktivitas bakteri terbaik selanjutnya diformulasikan ke dalam bentuk sediaan spray antiseptik.

\section{HASIL DAN PEMBAHASAN}

\subsection{Skrining Fitokimia dan Standardisasi Bahan}

Berdasarkan Tabel 1, analisis skrining fikokimia Chlorella vulgaris B menunjukkan bahwa bahan yang digunakan positif mengandung alkaloid, flavonoid, tannin, monoterpenoid dan seskuiterpenoid serta steroid. Adanya senyawa flavonoid di dalam bahan mejadikan bahan memiliki potensi kuat sebagai antibakteri (Syed et al, 2015). Selain flavonoid, adanya monoterpena dan seskuiterpena yang merupakan komposisi dari minyak atsiri, seringkali dihubungkan sebagai antibakteri (diastuti dkk, 2016; maulidya, 2018).

Tabel 1. Hasil Skrinning Fikokimia

\begin{tabular}{cc}
\hline Senyawa Metabolit & Hasil \\
\hline Alkaloid & + \\
\hline Flavonoid & + \\
\hline Saponin & - \\
\hline Tanin & + \\
\hline Kuinon & - \\
\hline Monoterpen/Seskuiterpen & + \\
\hline Steroid & + \\
\hline
\end{tabular}

Hasil standardisasi bahan yang ada di dalam Tabel 2 menunjukkan bahwa bahan mengandung senyawa larut air yang cukup besar. Hal ini ditunjukkan dengan nilai kadar sari larut air yaitu sebesar $36,44 \%$ yang artinya bahwa bahan kaya akan senyawa yang bersifat polar. Disamping senyawa polar, kandungan senyawa semi polar dan 
non polar juga cukup tinggi, dimana kadar sari larut etanol dari bahan adalah 33,84\%. Hal ini menunjukkan bahwa metode ekstraksi dengan menggunakan pelarut etanol diprediksikan mampu menarik banyak senyawa terkhusus metabolit sekunder baik yang bersifat non polar maupun semi polar.

Tabel 2. Hasil Parameter Standar

\begin{tabular}{lc}
\hline \multicolumn{1}{c}{ Parameter } & Hasil \\
\hline Kadar air & $8 \%$ \\
\hline Kadar sari larut air & $36,44 \%$ \\
\hline Kadar sari larut etanol & $33,84 \%$ \\
\hline Kadar abu total & $62,8 \%$ \\
\hline Kadar abu tidak larut asam & $0,3 \%$ \\
\hline
\end{tabular}

Berdasarkan Tabel 2, kadar abu yang cukup tinggi diangka $62,8 \%$ menunjukkan bahwa bahan kaya akan unsur logam anorganik fisiologis atau bisa dikenal sebagai logam ringan. Logam jenis ini cenderung larut didalam air. Meskipun memiliki kadar abu yang besar, namun bahan dapat dikatakan masih aman dimana kadar abu tidak larut asam berada dibawah $0,3 \%$. Hal ini menunjukkan bahwa unsur logam berat yang berbahaya bagi kesehatan cenderung berada dalam kadar yang rendah.

Ekstraksi bertujuan untuk mengambil senyawa metabolit sekunder dari bahan Alga hijau (Chlorella vulgaris). Proses ekstraksi menghasilkan ekstrak kental sebesar 119,3 g. Ekstraksi Cair-Cair (ECC) dilakukan untuk menghasilkan fraksi berdasarkan sifat polar, semipolar dan nonpolar. Pemisahan golongan senyawa bertujuan untuk meningkatkan aktivitas farmakologi, dan menghilangkan gangguan akibat interaksi antagonis antara senyawa yang memiliki aktifitas dengan senyawa lain yang dapat menurunkan aktivitas dari senyawa metabolit sekunder. Proses ECC menghasilkan fraksi n-heksan sebesar 4,7885 g, fraksi etil sebesar 0,7852 g, dan fraksi air sebesar 16,675 g. Data ini menunjukkan bahwa senyawa polar sangat mendominasi kandungan kimia dari ekstrak Alga hijau.

\subsection{Data Aktivitas Antibakteri Fraksi} terhadap Staphylococcus epidermidis

Berdasarkan Tabel 3, hasil uji aktivitas penghambatan pertumbuhan bakteri S.epidermidis pada fraksi n-heksan memiliki aktivitas yang paling baik dibandingkan kedua fraksi lainnya (fraksi air dan etil asetat). Fraksi n-heksana memberikan zona bening dengan ukuran diameter 16.1 pada konsentrasi $10 \%$.

Tabel 3. Hasil Pengujian Aktivitas

\begin{tabular}{lccc}
\hline \multirow{2}{*}{ Fraksi } & \multicolumn{3}{c}{ Zona Bening (mm) } \\
\cline { 2 - 4 } & $\mathbf{5 \%}$ & $\mathbf{8 \%}$ & $\mathbf{1 0 \%}$ \\
\hline $\begin{array}{l}\text { Fraksi n } \\
\text { heksan }\end{array}$ & 12.1 & 15.2 & 16.1 \\
\hline $\begin{array}{l}\text { Fraksi etil } \\
\text { asetat }\end{array}$ & 14.1 & 15.7 & 14.10 \\
\hline Fraksi air & - & - & - \\
\hline
\end{tabular}




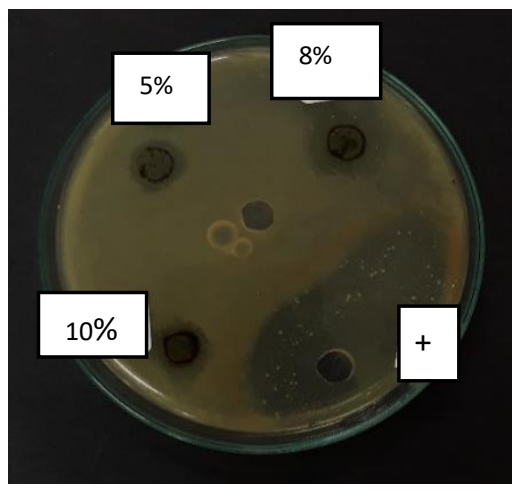

Gambar 1. Hasil Pengamatan Uji Aktivitas Antibakteri S. epidermidis Fraksi N-heksan

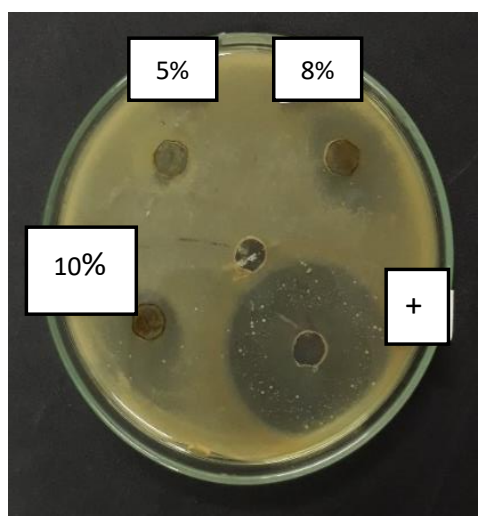

Gambar 2. Hasil Pengamatan Uji Aktivitas Antibakteri S. epidermidis Fraksi Etil asetat

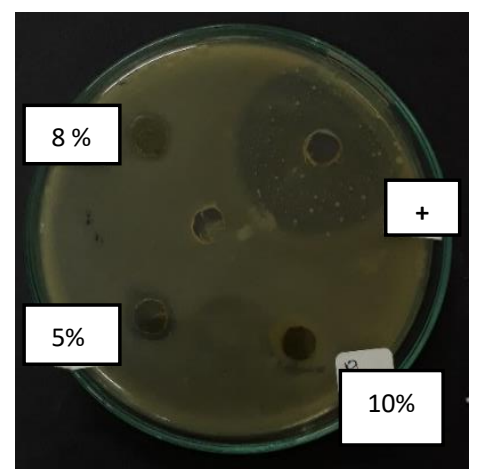

Gambar 3. Hasil Pengamatan Uji

Aktivitas Antibakteri S. epidermidis Fraksi Air

Berdasarkan hasil pengujian, adanya zona hambat pada fraksi n-heksan dan etil asetat disebabkan karena senyawa aktif di dalam fraksi mampu berdifusi ke dalam media sehingga bakteri $S$. epidermidis tidak mampu berkembang dengan baik. Sedangkan media yang berisi fraksi air tidak menghasilkan zona hambat, karena senyawa aktif di dalam fraksi tidak mampu berdifusi ke dalam media sehingga bakteri $S$. epidermidis masih berkembang. Hal ini dapat terjadi akibat perbedaan sifat kepolaran antara fraksi yang diuji, dimana menurut Coates, et al. (2014: 5) senyawa yang bersifat lebih non-polar mampu mencegah pembentukan koloni bakteri dengan merusak membran sel bakteri Staphylocccus.

Mekanisme penghambatan ini terjadi karena adanya penghambatan sintesis membran sel bakteri. Mekanisme penghambatan ini terjadi karena adanya penghambatan sintesis membran sel bakteri. Kerusakan pada membran sel ini memungkinkan nukleotida dan asam amino keluar dari sel, selain itu kerusakan ini dapat mencegah masuknya bahan-bahan penting ke dalam sel.

Berdasarkan data skrining fikokimia yang tertera pada Tabel 1, senyawa alkaloid yang terkandung di dalam alga hijau Chlorella vulgaris B diduga memiliki aktivitas antibakteri. Senyawa alkaloid memiliki mekanisme penghambatan dengan cara mengganggu komponen penyusun peptidoglikan pada sel bakteri, sehingga lapisan dinding sel tidak terbentuk secara utuh dan menyebabkan kematian sel (Gunawan, 2009). Senyawa flavonoid yang 
merupakan golongan senyawa fenol dapat mengubah tegangan permukaan, sehingga merusak permeabilitas selektif dari membran sel mikroba yang menyebabkan keluarnya metabolik penting. Senyawa tannin menunjukkan aktivitas antibakterinya dengan cara berikatan dengan proline yang kaya akan protein membentuk suatu kompleks, menyebabkan protein leakage sehingga terjadi kerusakan dinding sel bakteri dan mengakibatkan kematian bakteri (Maftuhah, et al.2015).

Aktivitas fraksi terbaik, yaitu fraksi n-heksan dengan konsentrasi 10\%, selanjutnya diformulasikan ke dalam sediaan spray antiseptik sebagai bahan aktif, yang dapat dilihat pada Gambar 4. Bentuk sediaan yang dipilih adalah bentuk cairan atau liquida dengan bahan yang digunakan adalah isolat berupa fraksi yang berperan sebagai zat aktif, serta Pine oil dan Aquadest sebagai bahan tambahan. Sediaan cair yang dibuat berwarna hijau terang dan memiliki bau khas fraksi. Sediaan ini juga memiliki bobot jenis sediaan sebesar 1.0047 .

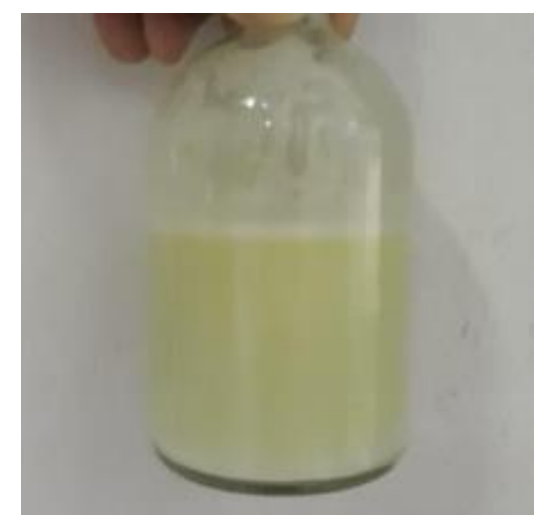

Gambar 4. Sediaan Spray Antiseptik

\section{KESIMPULAN}

Mikroalga hijau (Chlorella vulgaris B) memiliki aktivitas terhadap salah satu bakteri penyebab infeksi kulit, yaitu Staphylococcus epidermidis, yang ditunjukkan oleh adanya aktivitas penghambatan terbaik yang ditunjukkan dengan adanya zona hambat dari fraksi $n$ heksan dengan konsentrasi sebesar $10 \%$.

\section{DAFTAR PUSTAKA}

Amaro H., Guedes C., Malcata X. 2011. Antimicrobial Activities of Microalgae, Journal of Science Against Microbial Pathogens.:12711280.

Chessa D., Ganau G., Mazzarello V. 2015. Review : An overview of Staphylococcus epidermidis and Staphylococcus aureus with a focus on developing countries, $J$ Infect Dev Ctries, 9(6):547-550.

Chessa D., Ganau G., Spiga L., Bulla A., Mazzarello V., Campus GV., Rubino S. 2016. Staphylococcus aureus and Staphylococcus epidermidis Virulence Strains as Causative Agents of Persistent Infections in Breast Implants, PLoS ONE, 11(1): e0146668.

Coates, R., Moran, J., Horsburgh, M. J. 2014. Staphylococci: clonizers and pathogens on human skin. Journal Future Microbiology, 9(1): 75-91.

Diastuti H., Syah YM., Juliawaty LD., Singgih M., 2016, Aktivitas Antibakteri Seskuiterpen Germakron dari Rimpang Curcuma xanthorrhiza., ALCHEMY Jurnal Penelitian Kimia, 12(2):103-111.

European Centre for Disease Prevention and Control (ECDC), 2018. Rapid risk assassement Multidrug-resistant Staphylococcus epidermidis, Stockholm Download from 
https://ecdc.europa.eu/ tanggal akses 16 Juli 2019.

Ghasemi Y., Moradian A., Ali AM., Sokhravi S., Morowvat M., 2007. Antifungal and Antibacterial Activity of the Microalgae Collected from Paddy Fields of Iran: Characterization of Antimicrobial Activity of Chroococcus disperses. Journal of Biological Sciences, 7(6):904-910.

Gunawan IGW., Gede B \& Sutrisnayanti NL. 2008. Isolasi dan Identifikasi Senyawa Terpenoid yang Aktif Antibakteri pada Herba Meniran (Phyllanthus Niruri Linn). Jurnal Kimia 2(1): 31-39.

KaBPOM RI No. HK.00.05.41.1384, 2005 tentang Kriteria dan Tatalaksana Pendaftaran Obat Tradisional, Obat Herbal terstandar dan Fitofarmaka.

Maftuhah A., Bintari H., Mustikaningtyas D. 2015. Pengaruh Infusa daun beluntas (Pluchea Indica) Terhadap Pertumbuhan bakteri TERHADAP PERTUMBUHAN BAKTERI Staphylococcus Epidermidis. Semarang: Universitas Negeri Semarang.

Maulidya R., Aisyah Y., Haryani S. 2018. Pengaruh Jenis Bunga dan Waktu Pemetikan Terhadap Sidat Fisikokimia dan Aktivitas Antibakteri Minyak Atsiri Bungan Kenanga (Cananga odorata), Jurnal Teknologi dan Industri Pertanian Indonesia, 8(2):53-60.

Meskin I. 1998. Staphylococcus epidermidis, Pediatrics in Review 19(3):105 DOI: 10.1542/pir.19-3105, Downloaded from http://pedsinreview.aappublications.or g/ tanggal akses 16 July 2019.

Octaviani M., Fadhli H., Yuneistya E. 2019. Uji Aktivitas Antimikroba Ekstrak Etanol dari Kulit Bawang Merah (Allium cepa L.) dengan Metode Difusi Cakram, Pharmaceutical sciences and Research (PSR), 6(1): $62-68$.

Pandey SK \& Kim KH. 2011. Human Bodyodor Components and Their
Determination. Trends in Analytical Chemistry, 30(5):784-796.

Safi C, Zebib B., Merah O, \& Pierre YvesPontalier. 2014. Morphology, Composition, Production, Processing and a Hallications of Chlorella vulgaris: A review. Elsevier, 35:265278.

Syed, Shabudeen. 2015. The Uses of Chlorella Vulgaris as Antimicrobial Agent and as a Diet: the Presence of Bio-active Compounds which caters the Vitamins, Minerals in General: 188.

Tiwari P., Kumar B., Kaur M., Kaur G., Kaur H. 2011, Phytochemical screening and Extraction: A Review, International Pharmaceutica Sciencia 1(1): 98-106. 